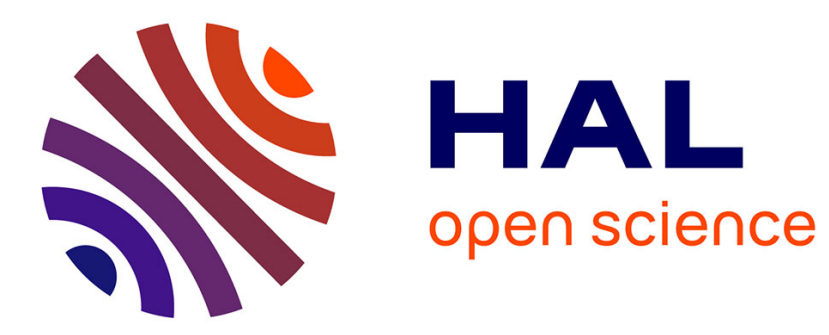

\title{
Determination of Low Molecular Weight Dicarboxylic and Ketocarboxylic Acids in Seawater Samples
}

Marc Tedetti, Kimitaka Kawamura, Bruno Charrìre, Nicolas Chevalier, Richard Sempere

\section{- To cite this version:}

Marc Tedetti, Kimitaka Kawamura, Bruno Charrìre, Nicolas Chevalier, Richard Sempere. Determination of Low Molecular Weight Dicarboxylic and Ketocarboxylic Acids in Seawater Samples. Analytical Chemistry, 2006, 78 (17), pp.6012-6018. 10.1021/ac052226w . hal-01999300

\section{HAL Id: hal-01999300 \\ https://hal.science/hal-01999300}

Submitted on 9 Feb 2019

HAL is a multi-disciplinary open access archive for the deposit and dissemination of scientific research documents, whether they are published or not. The documents may come from teaching and research institutions in France or abroad, or from public or private research centers.
L'archive ouverte pluridisciplinaire HAL, est destinée au dépôt et à la diffusion de documents scientifiques de niveau recherche, publiés ou non, émanant des établissements d'enseignement et de recherche français ou étrangers, des laboratoires publics ou privés. 


\title{
Determination of Low Molecular Weight Dicarboxylic and Ketocarboxylic Acids in Seawater Samples
}

\author{
Marc Tedetti, † Kimitaka Kawamura,‡ Bruno Charrière,† Nicolas Chevalier,† and Richard Sempéré*,†
}

Laboratoire de Microbiologie Géochimie et Ecologie Marines (LMGEM), CNRS/INSU, UMR 6117, Centre d'Océanologie de Marseille, Université de la Méditerranée, Campus de Luminy, Case 901, F-13 288 Marseille Cedex 9, France, and Institute of Low-Temperature Science, Hokkaido University, N19 W8, Kita-ku, Sapporo 060-0819, Japan

\begin{abstract}
We report a new method developed for the isolation and determination of low molecular weight dicarboxylic acids and related polar compounds $\left(\mathrm{C}_{2}-\mathrm{C}_{9}\right)$ from seawater samples. The seawater sample was first acidified and then passed through an activated charcoal column to adsorb the dicarboxylic acids. They are then desorbed with $\mathrm{NH}_{4} \mathrm{OH} /$ methanol/water mixture and derivatized with $\mathrm{BF}_{3}$ /1-butanol to dibutyl esters, which are determined using a capillary GC/FID. We tested different $\mathrm{pH}(0.5$, $1,1.5)$ and different amounts of charcoal $(100,200,300$, $500 \mathrm{mg}$ ) to maximize the recovery of dicarboxylic acids. Using $300 \mathrm{mg}$ of activated charcoal for $100 \mathrm{~mL}$ of sodium chloride solution acidified at $\mathrm{pH} 1$, the recoveries for $\mathrm{C}_{2}$, $\mathrm{C}_{3}, \mathrm{C}_{4}, \mathrm{C}_{5}, \mathrm{C}_{6}, \mathrm{C}_{7}, \mathrm{C}_{8}$, and $\mathrm{C}_{9}$ were $61,49,96,84,77$, 67,57 , and $53 \%$, respectively. We applied this method to real seawater samples collected from the northwestern Mediterranean Sea. Here, we report, for the first time, concentrations of a homologous series of $\mathrm{C}_{2}-\mathrm{C}_{9}$ dicarboxylic acids as well as ketocarboxylic acids including glyoxylic and 4-oxobutanoic acids in surface water and deep seawater samples, with glyoxylic acid being the dominant species $\left(8^{-40} \mu \mathrm{g} \mathrm{L}^{-1}\right)$. This method allows the detection of dicarbonyls such as glyoxal in the samples although its quantification is not possible.
\end{abstract}

Low molecular weight (LMW) dicarboxylic acids and related polar compounds (DCAs) $\left(\mathrm{C}_{2}-\mathrm{C}_{9}\right)$ are ubiquitous water-soluble organic compounds that have been detected in a variety of environmental samples including atmospheric aerosols, ${ }^{1,2}$ rainwaters, ${ }^{3}$ snowpacks, ${ }^{4}$ ice cores, ${ }^{5}$ meteorites, ${ }^{6}$ marine sediments,,${ }^{7,8}$

\footnotetext{
* Corresponding author. Fax: 3304918296 41. E-mail: sempere@ com.univ-mrs.fr.

† Université de la Méditerranée.

‡ Hokkaido University.

(1) Kawamura, K.; Ikushima, K. Environ. Sci. Technol. 1993, 27, 2227-2235.

(2) Kawamura, K.; Watanabe, T. Anal. Chem. 2004, 76, 5762-5768.

(3) Sempéré, R.; Kawamura, K. Atmos. Environ. 1996, 30, 1609-1619.

(4) Narukawa, M.; Kawamura, K.; Li, S.-M.; Bottenheim, J. W. Atmos. Environ. 2002, 36, 2491-2499.

(5) Kawamura, K.; Yokoyama, K.; Fujii, Y.; Watanabe, O. J. Geophys. Res. 2001, 106, 1331-1345.

(6) Peltzer, E. T.; Bada, J. L.; Schlesinger, G.; Miller, S. L. Adv. Space Res. 1984, 4, 69-74.

(7) Peltzer, E. T.; Bada, J. L. Geochim. Cosmochim. Acta 1981, 45, 1847-1854.

(8) Gogou, A.; Stephanou, E. G. Mar. Chem. 2004, 85, 1-25.
}

hypersaline brines, ${ }^{9}$ and freshwaters. ${ }^{10-12}$ In the atmosphere, DCAs originate from incomplete combustion of fossil fuels, ${ }^{13}$ biomass burning, ${ }^{14}$ direct biogenic emission, ${ }^{15}$ and ozonolysis and photooxidation of organic compounds. ${ }^{16,17}$ Because of their hygroscopic properties, DCAs can act as cloud condensation nuclei and have an impact on the radiative forcing at the Earth's surface. ${ }^{18}$ DCAs also participate in many biological processes. They are important intermediates in the tricarboxylic acid and glyoxylate cycles and the catabolism and anabolism of amino acids. ${ }^{19}$

In seawater, DCAs may be produced by phytoplankton photorespiration, ${ }^{20}$ photochemical degradation of dissolved organic matter (DOM), ${ }^{21,22}$ and microbial degradation of long-chain lipids. ${ }^{23}$ Other possible sources of DCAs in seawater include diffusion from surface sediments (especially for oxalic acid), ${ }^{7}$ inputs of terrigenous material from rivers, ${ }^{22}$ and wet and dry depositions. ${ }^{16}$ Therefore, DCAs could represent a non-negligible fraction of LMW DOM and have a potential role in the organic carbon cycle in the marine environment. However, only a few studies have reported concentrations of DCAs or related compounds in seawater.

In the Pacific Ocean and coastal waters off California and Peru, one dicarboxylic acid, i.e., oxalic acid, and two ketocarboxylic acids (glyoxylic and pyruvic) were detected by reversed-phase and size exclusion HPLC using derivatization with o-phenelene diamine followed by an acetonitrile extraction. ${ }^{19,20}$ In the Sargasso Sea and coastal waters off Florida, ketocarboxylic acids (glyoxylic and pyruvic) and dicarbonyls (methylglyoxal and glyoxal) were

(9) Kawamura, K.; Nissenbaum, A. Org. Geochem. 1992, 18, 469-476.

(10) Bertilsson, S.; Tranvik, L. J. Limnol. Oceanogr. 2000, 45, 753-762.

(11) Brinkmann, T.; Hörsch, P.; Sartorius, D.; Frimmel, F. H. Environ. Sci. Technol. 2003, 37, 4190-4198.

(12) Goldstone, J. V.; Pullin, M. J.; Bertilsson, S.; Voelker, M. Environ. Sci. Technol. 2002, 36, 364-372.

(13) Kawamura, K.; Kaplan, I. R. Environ. Sci. Technol. 1987, 21, 105-110.

(14) Narukawa, M.; Kawamura, K.; Takeuchi, N.; Nakajima, T. Geophys. Res. Lett. 1999, 26, 3101-3104.

(15) Kawamura, K.; Gagosian, R. B. J. Atmos. Chem. 1990, 11, 107-122.

(16) Sempéré, R.; Kawamura, K. Global Biogeochem. Cycles 2003, 17, 38, 1-38, 15.

(17) Kawamura, K.; Imai, Y.; Barrie, L. A. Atmos. Environ. 2005, 39, 599-614.

(18) Kerminen, V.-M.; Ojanen, C.; Pakkanen, T.; Hillamo, R.; Aurela, M.; Merilainen, J. J. Aerosol Sci. 2000, 31, 349-362.

(19) Steinberg, S. M.; Bada, J. L. Mar. Chem. 1982, 11, 299-306.

(20) Steinberg, S. M.; Bada, J. L. J. Mar. Res. 1984, 42, 697-708.

(21) Kirk, J. T. O. Arch. Hydrobiol. 1994, 43, 1-16.

(22) Pullin, M. J.; Bertilsson, S.; Goldstone, J. V.; Voelker, B. M. Limnol. Oceanogr. 2004, 49, 2011-2022.

(23) Kester, A. S.; Foster, J. W. J. Bacteriol. 1963, 85, 859-869. 
detected by reversd-phase HPLC using derivatization with 2,4dinitrophenylhydrazine. ${ }^{24-26}$ However, there is no report dealing with a complete distribution of $\mathrm{C}_{2}-\mathrm{C}_{9}$ DCAs in seawater. This paucity of data on DCAs in seawater results in large part from a lack of suitable chromatography methods with sufficient sensitivity, combined with the high volatility of the compounds and the large amount of sea salts, which can interfere with the absorption of DCAs during the procedure leading to low recoveries. Consequently, the accurate concentrations of DCAs in the ocean are still unknown. The methods for isolation of DOM from seawater include mainly electrodialysis, solvent extraction, ultrafiltration, and solid-phase extraction. ${ }^{27}$ The latter involves adsorption on activated charcoal and adsorption on ion exchange and Amberlite XAD resins..$^{27,28}$ Difficulties of the methods are the evaporation of large volumes of water, selectivity for specific classes of compounds, low recoveries of extraction, and high blank. ${ }^{28}$

In this study, we chose activated charcoal to isolate DCAs $\left(\mathrm{C}_{2}-\right.$ $\mathrm{C}_{9}$ ) from seawater samples. Indeed, charcoal is easily pretreated, blank values can be minimized using large sample volumes, the major portion of DOM is adsorbed, and small volumes of eluting solvents are required to remove the adsorbed DOM. ${ }^{29}$ Our technique consists of the adsorption of DCAs from acidified seawater onto activated, pretreated charcoal followed by desorption using different eluents. DCAs are then derivatized with $\mathrm{BF}_{3} /$ 1-butanol to dibutyl esters and detected by GC/FID-MS. The derivatization technique has been reported as an efficient method for a simultaneous detection of $\mathrm{C}_{2}-\mathrm{C}_{9}$ dicarboxylic acids and $\mathrm{C}_{2}-$ $\mathrm{C}_{9}$ ketocarboxylic acids and dicarbonyls (glyoxal and methylglyoxal) in rainwater samples. ${ }^{30}$ The method we report here was first tested in sodium chloride solutions amended with authentic DCAs and then applied to seawater samples from the northwestern Mediterranean Sea.

\section{EXPERIMENTAL SECTION}

Material and Reagents. Activated charcoal (powdered, pro analysis for CG, $100 \mathrm{~g}$, particle size $0.3-0.5 \mathrm{~mm}$, bulk density 0.41 $\mathrm{g} \mathrm{cm}^{-3}$ ) and acetonitrile (GC gradient grade) were purchased from Fluka (Saint-Quentin Fallavier, France). Methanol, $n$-hexane, and dichloromethane (Supra Solv) were from Merck (Strasbourg, France), ammonia (25\%, Normapur) was from Prolabo (Strasbourg, France), $14 \% \mathrm{BF}_{3} / 1$-butanol was from Alltech Associates (Templemars, France), and hydrochloric acid (20\%, doubledistilled, PPB/Teflon grade), sodium hydroxide (pellets), and humic acid were from Sigma-Aldrich (Saint-Quentin Fallavier, France). Sodium chloride (Acros Organics, Strasbourg, France) was heated at $450{ }^{\circ} \mathrm{C}$ for $6 \mathrm{~h}$ before use. Authentic $\alpha, \omega$-dicarboxylic acids $\left(\mathrm{C}_{2}-\mathrm{C}_{9}\right)$ including maleic $(\mathrm{M})$ and fumaric $(\mathrm{F})$ acids, phthalic $(\mathrm{Ph})$ acid and ketocarboxylic acids (glyoxylic $\left(\omega \mathrm{C}_{2}\right)$, 4-oxobutanoic $\left(\omega \mathrm{C}_{4}\right)$ acids, and dicarbonyl (glyoxal), were obtained from SigmaAldrich. All reagent solutions were prepared in Milli-Q water obtained from a Millipore unit with a UV organic oxidation attachment. Glassware was heated at $450{ }^{\circ} \mathrm{C}$ for $6 \mathrm{~h}$ and rinsed

(24) Mopper, K.; Stahovec, W. L. Mar. Chem. 1986, 19, 305-321.

(25) Kieber, D. J.; Mopper, K. Mar. Chem. 1987, 21, 135-149.

(26) Zhou, X.; Mopper, K. Mar. Chem. 1997, 56, 201-213.

(27) Benner, R. In Biogeochemistry of Marine Dissolved Organic Matter; Hansell,

A., Carlson, C. A., Eds.; Academic Press: New York, 2002; pp 59-90.

(28) Kerr, R. A.; Quinn, J. G. Deep-Sea Res. 1975, 22, 107-116.

(29) Jeffrey, L. M.; Hood, D. W. J. Mar. Res. 1958, 17, 247-271.

(30) Kawamura, K. Anal. Chem. 1993, 65, 3505-3511. successively with Milli-Q water, methanol, and dichloromethane before use.

Principle of Solid-Phase Extraction. Water samples were acidified before solid-phase extraction of DCAs. Acidification releases DCAs as free protonated species in solution and increases the efficiency of DCA extraction because hydrophobic interactions are the primary mechanism for adsorption onto activated charcoal. During the passage of the sample through the column onto activated charcoal, DCAs are continually adsorbed from the mobile phase to the stationary phase while salts are eliminated. DCAs are then desorbed from charcoal and collected in a salt-free solution using a mixture of alkaline solutions and organic solvents. . $^{28,31}$

Pretreatment of Activated Charcoal. Before use, activated charcoal was heated at $700{ }^{\circ} \mathrm{C}$ for $4 \mathrm{~h}$ in the presence of air in a porcelain flask, transferred in a 250 -mL glass flask, and extracted with different solvents to remove contaminants. Charcoal was stirred vigorously for $1 \mathrm{~h}\left(20-25^{\circ} \mathrm{C}\right)$ in $1 \mathrm{~N} \mathrm{NaOH}$, methanol, 6 $\mathrm{N} \mathrm{HCl}, 7 \mathrm{~N} \mathrm{NH}_{4} \mathrm{OH}$ in water, $6 \mathrm{~N} \mathrm{HCl}$, methanol, and Milli-Q water. This procedure was repeated twice. After each solvent extraction, charcoal was rinsed several times with Milli-Q water whereas small particles were removed by decantation. Finally, charcoal was dried using a rotary evaporator under a vacuum, heated at $450{ }^{\circ} \mathrm{C}$ for $5 \mathrm{~h}$ in the presence of air, and stored at -18 ${ }^{\circ} \mathrm{C}$.

Isolation of Dicarboxylic Acids. In a precombusted glass column (20-cm length, $0.7-\mathrm{cm}$ internal diameter), a pretreated activated charcoal $(100,200,300$, or $500 \mathrm{mg}$ ) was packed with quartz wool (rinsed several times with methanol). After passing Milli-Q water $(30 \mathrm{~mL}), 100 \mathrm{~mL}$ of sample was passed through the column. The sample was a solution of sodium chloride $\left(35 \mathrm{~g} \mathrm{~L}^{-1}\right.$ $\mathrm{NaCl}$ in Milli-Q water) acidified to $\mathrm{pH} 0.5,1$, or 1.5 by addition of $6 \mathrm{~N} \mathrm{HCl}$ and spiked with authentic DCAs $\left(50 \mu \mathrm{g} \mathrm{L^{-1 }}\right.$ final concentration). The flow rate of sample into the column was $\sim 1$ $\mathrm{mL} \mathrm{min}^{-1}$. After passing the sample, DCAs were desorbed from charcoal with successively $7 \mathrm{~N} \mathrm{NH}_{4} \mathrm{OH}$ in water $(20 \mathrm{~mL}), 7 \mathrm{~N}$ $\mathrm{NH}_{4} \mathrm{OH}$ in water/methanol $(50 / 50,20 \mathrm{~mL})$, methanol $(30 \mathrm{~mL})$, and Milli-Q water $(30 \mathrm{~mL})$. The flow rate of eluents into the column was $\sim 2 \mathrm{~mL} \min ^{-1}$. The temperature was constant during the procedure $\left(22 \pm 2{ }^{\circ} \mathrm{C}\right)$. The $100-\mathrm{mL}$ solution obtained was stored at $4{ }^{\circ} \mathrm{C}$ in the dark for $15-20 \mathrm{~h}$ before $\mathrm{BF}_{3} / 1$-butanol derivatization.

Butyl Ester Derivatization of Dicarboxylic Acids. The sample was first concentrated down to $3-4 \mathrm{~mL}$ using a rotary evaporator under a vacuum, then transferred into a 25 -mL pearshaped flask, further concentrated by the rotary evaporator, and finally concentrated to almost dryness under a nitrogen stream. A total of $0.25 \mathrm{~mL}$ of $14 \% \mathrm{BF}_{3} / 1$-butanol was immediately added to the sample, and the flask was sealed with a glass stopper, Teflon tape, and clamp. The organic acids and reagent were mixed with ultrasonication for $1 \mathrm{~min}$ and then heated at $100{ }^{\circ} \mathrm{C}$ for $30 \mathrm{~min}$ to derive dibutyl esters for the carboxyl group and dibutoxy acetal for the aldehyde group. The derivatives were extracted with 5 $\mathrm{mL}$ of $n$-hexane after adding $3 \mathrm{~mL}$ of Milli-Q water and $0.2 \mathrm{~mL}$ of acetonitrile. The hexane layer was further washed with Milli-Q water $(3 \times 3 \mathrm{~mL})$. The derivatives were dried by using a rotary evaporator, and then a nitrogen stream and were finally dissolved

(31) Kerr, R. A.; Quinn, J. G. Mar. Chem. 1980, 8, 217-229. 
Table 1. Recoveries of DCAs Spiked into Sodium Chloride Solutions Acidified to pH 0.5 , 1, and 1.5 Using 100, 200, 300, and $500 \mathrm{mg}$ of Activated Charcoala

\section{compounds}

oxalic acid, $\mathrm{C}_{2}$

malonic acid, $\mathrm{C}_{3}$

succinic acid, $\mathrm{C}_{4}$

glutaric acid, $\mathrm{C}_{5}$

adipic acid, $\mathrm{C}_{6}$

pimelic acid, $\mathrm{C}_{7}$

suberic acid, $\mathrm{C}_{8}$

azelaic acid, $\mathrm{C}_{9}$

maleic acid, $M$

fumaric acid, F

phthalic acid, $\mathrm{Ph}$

glyoxylic acid, $\omega \mathrm{C}_{2}$

4-oxobutanoic acid, $\omega \mathrm{C}_{4}$

glyoxal

\begin{tabular}{|c|c|c|c|c|c|c|c|c|c|c|c|}
\hline \multicolumn{3}{|c|}{$100 \mathrm{mg}$} & \multicolumn{3}{|c|}{$200 \mathrm{mg}$} & \multicolumn{3}{|c|}{$300 \mathrm{mg}$} & \multicolumn{3}{|c|}{$500 \mathrm{mg}$} \\
\hline $\mathrm{pH} 0.5$ & $\mathrm{pH} 1$ & $\mathrm{pH} 1.5$ & $\mathrm{pH} 0.5$ & $\mathrm{pH} 1$ & $\mathrm{pH} 1.5$ & $\mathrm{pH} 0.5$ & $\mathrm{pH} 1$ & $\mathrm{pH} 1.5$ & $\mathrm{pH} 0.5$ & $\mathrm{pH} 1$ & $\mathrm{pH} 1.5$ \\
\hline 31 & $24 \pm 3$ & 11 & 65 & $42 \pm 9$ & 23 & 53 & $61 \pm 8$ & 20 & 60 & $59 \pm 10$ & 34 \\
\hline 9 & $24 \pm 3$ & 14 & 16 & $45 \pm 1$ & 27 & 35 & $49 \pm 10$ & 17 & 44 & $55 \pm 5$ & 28 \\
\hline 64 & $67 \pm 7$ & 46 & 59 & $88 \pm 9$ & 56 & 80 & $96 \pm 6$ & 43 & 85 & $96 \pm 11$ & 56 \\
\hline 64 & $66 \pm 6$ & 51 & 55 & $81 \pm 7$ & 64 & 74 & $84 \pm 7$ & 41 & 81 & $83 \pm 9$ & 54 \\
\hline 65 & $61 \pm 6$ & 52 & 54 & $76 \pm 6$ & 68 & 75 & $77 \pm 8$ & 40 & 81 & $76 \pm 8$ & 55 \\
\hline $\mathrm{nd}^{b}$ & $53 \pm 5$ & nd & nd & $68 \pm 8$ & nd & nd & $67 \pm 8$ & nd & nd & $66 \pm 8$ & nd \\
\hline nd & $43 \pm 5$ & nd & nd & $57 \pm 4$ & nd & nd & $57 \pm 8$ & nd & nd & $56 \pm 10$ & nd \\
\hline 54 & $40 \pm 4$ & 41 & 43 & $53 \pm 4$ & 57 & 61 & $53 \pm 10$ & 34 & 68 & $52 \pm 8$ & 44 \\
\hline nd & $38 \pm 6$ & nd & nd & $41 \pm 5$ & nd & nd & $44 \pm 4$ & nd & nd & $39 \pm 2$ & nd \\
\hline nd & $95 \pm 7$ & nd & nd & $119 \pm 6$ & nd & nd & $115 \pm 8$ & nd & nd & $122 \pm 15$ & nd \\
\hline nd & $41 \pm 5$ & nd & nd & $55 \pm 1$ & nd & nd & $41 \pm 8$ & nd & nd & $48 \pm 8$ & nd \\
\hline nd & 0 & nd & nd & $1 \pm 0$ & nd & nd & $1 \pm 0$ & nd & nd & $1 \pm 2$ & nd \\
\hline nd & $12 \pm 1$ & nd & nd & $19 \pm 1$ & nd & nd & $17 \pm 3$ & nd & nd & $16 \pm 4$ & nd \\
\hline nd & 0 & nd & nd & 0 & nd & nd & 0 & nd & nd & $2 \pm 1$ & nd \\
\hline
\end{tabular}

${ }^{a}$ Averaged percentages are given with a standard deviation based on triplicate analyses. Recoveries were corrected for the blank values. The sodium chloride solutions $(100 \mathrm{~mL})$ were acidified, amended with DCAs (50 $\mu \mathrm{g} \mathrm{L} \mathrm{L}^{-1}$ final concentration), passed through charcoal, eluted, and derivatized. ${ }^{b}$ nd, not determined.

in $100 \mu \mathrm{L}$ of $n$-hexane before gas chromatography-FID determination. 1,17

Gas Chromatography Conditions. The dibutyl esters were determined with a Perkin-Elmer autosystem XL gas chromatograph equipped with a split/splitless injector, a fused-silica capillary column (HP-5, $25 \mathrm{~m} \times 0.32 \mathrm{~mm} \times 0.52 \mu \mathrm{m}$, HewlettPackard), and an FID detector. GC conditions were as follows: injection temperature of $250^{\circ} \mathrm{C}$; column oven temperature of 50 ${ }^{\circ} \mathrm{C}(2 \mathrm{~min})$ programmed to $120{ }^{\circ} \mathrm{C}$ at $30{ }^{\circ} \mathrm{C} \mathrm{min}-1$, then to $300{ }^{\circ} \mathrm{C}$

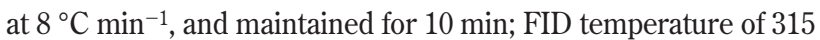
${ }^{\circ} \mathrm{C} .{ }^{1}$ Peak areas were calculated with a Turbochrom v4 integrator. Peak identification was performed by a comparison of GC retention times with those of dibutyl ester standards. For seawater samples, the identification of DCAs was also confirmed with a GC/MS (ThermoQuest Trace MS system) under similar GC conditions. ${ }^{17}$

Application to Seawater Samples. Seawater samples were collected in the northwestern Mediterranean Sea (Bay of Marseille $\left(43^{\circ} 18^{\prime} \mathrm{N}, 05^{\circ} 22^{\prime} \mathrm{E}\right)$ and at Dyfamed station $\left.\left(43^{\circ} 25^{\prime} \mathrm{N}, 07^{\circ} 52^{\prime} \mathrm{E}\right)\right)$ in September and October 2005, respectively. In the Bay of Marseille, samples were collected on the surface using 2-L glass bottles. At the Dyfamed station, samples were collected at 5-, 100-, and 1500-m depth using 10-L Niskin bottles equipped with Viton O-rings and silicone tubing. Samples were immediately filtrated through precombusted $\left(450^{\circ} \mathrm{C}\right.$ for $6 \mathrm{~h}$ ) GFF filters ( $47-\mathrm{mm}$ filter diameter, rinsed with $2 \mathrm{~L}$ of Milli-Q water and $150 \mathrm{~mL}$ of sample prior to filtration) and then through $0.2-\mu \mathrm{m}$ polycarbonate filters (Nuclepore $47-\mathrm{mm}$ filter diameter, rinsed with $10 \% \mathrm{HCl}, 2 \mathrm{~L}$ of Milli-Q water, and $150 \mathrm{~mL}$ of sample prior to filtration) in a precombusted glass apparatus. After filtration, duplicate subsamples $(10 \mathrm{~mL})$ were acidified with $85 \%$ phosphoric acid and stored in the dark in combusted, Teflon-capped glass vials for dissolved organic carbon (DOC) analyses. DOC concentrations were measured using a Shimadzu TOC-5000 carbon analyzer. ${ }^{32}$ Samples for DCAs analy-

(32) Sempéré, R.; Dafner, E.; Van Wambeke, F.; Lefèvre, D.; Magen, C.; Allègre, S.; Bruyant, F.; Bianchi, M.; Prieur, L. J. Geophys. Res. 2003, 108, C11, 3361, 10.1029/2002JC001475. ses were transferred into 500-mL precombusted bottles, poisoned with $\mathrm{HgCl}_{2}$ (10 $\mathrm{mg} \mathrm{L}^{-1}$ final concentration) to avoid any biological activity and stored at $4{ }^{\circ} \mathrm{C}$ in the dark until solid-phase extraction. Some of seawater samples (Bay of Marseille) were amended with authentic DCAs (from 0.1 to $9.5 \mu \mathrm{g} \mathrm{L}^{-1}$ final concentration) to perform spike experiments. All the seawater analyses were conducted in duplicate in the laboratory in Marseille.

\section{RESULTS AND DISCUSSION}

Extraction of Dicarboxylic Acids in Sodium Chloride Solutions. Table 1 present recoveries of extraction in the spiked sodium chloride solutions (100 mL of $35 \mathrm{~g} \mathrm{~L}^{-1} \mathrm{NaCl}$ amended with $50 \mu \mathrm{g} \mathrm{\textrm {L } ^ { - 1 }}$ DCAs) acidified at $\mathrm{pH} 0.5,1$, and 1.5 for 100,200 , 300 , and $500 \mathrm{mg}$ of activated charcoal. Recoveries were corrected for the procedural blanks, in which no serious contamination peaks were observed, except for $\mathrm{C}_{2}, \omega \mathrm{C}_{2}$, and glyoxal.

(a) pH Effect. Whatever the amount of charcoal, recoveries for $\mathrm{C}_{2}, \mathrm{C}_{3}, \mathrm{C}_{4}, \mathrm{C}_{5}, \mathrm{C}_{6}$, and $\mathrm{C}_{9}$ were systematically lower at $\mathrm{pH} 1.5$ than at $\mathrm{pH} 1$ (Table 1). This means that, at $\mathrm{pH} 1.5$, adsorption onto charcoal is less efficient due probably to a partial protonation of DCAs. Whatever the amount of charcoal, recoveries at $\mathrm{pH} 0.5$ were equal or higher $\left(\mathrm{C}_{2}\right)$, systematically lower $\left(\mathrm{C}_{3}\right)$, or equal or lower $\left(\mathrm{C}_{4}, \mathrm{C}_{5}, \mathrm{C}_{6}, \mathrm{C}_{9}\right)$ than at $\mathrm{pH} 1$ (Table 1$)$. These results suggest that the decrease in $\mathrm{pH}$ from 1 to 0.5 does not lead to a significant increase in adsorption, even for $\mathrm{C}_{2}$, which presents the lowest $\mathrm{p} K_{\mathrm{a}}$ (1.2). The decrease in $\mathrm{C}_{3}$ recovery is most likely due to an increase in the decarboxylation process (see below) and rather difficult to limit at low $\mathrm{pH}$. Therefore, $\mathrm{pH} 1$ was selected as the best $\mathrm{pH}$ condition since higher or lower $\mathrm{pH}$ limits the adsorption efficiency of the rest of the DCAs. Consequently, only $\mathrm{pH} 1$ was considered in the rest of this report.

(b) Amount of Charcoal Effect. For $\mathrm{C}_{2}$, the blank value for $100,200,300$, and $500 \mathrm{mg}$ represented $18,19,16$, and $26 \%$ of the value measured in the spiked samples, respectively. For $\omega \mathrm{C}_{2}$ and glyoxal, the blank values for $100,200,300$, and $500 \mathrm{mg}$ represented $61,34,34$, and $77 \%$ and $51,48,63$, and $69 \%$ of the values measured in the spiked samples, respectively. Whatever the amount of 
charcoal, recoveries increase from $\mathrm{C}_{2}$ to $\mathrm{C}_{4}$, without any significant difference between $\mathrm{C}_{2}$ and $\mathrm{C}_{3}$, and decrease from $\mathrm{C}_{4}$ to $\mathrm{C}_{9}$ (Table $1)$. They remain low for $M(\sim 40 \%)$ and very high for $F$ (more than 100\%). The lowest recoveries, observed for $\omega \mathrm{C}_{2}$ and glyoxal, explain the relative high percentage of blank values for these compounds (Table 1).

When charcoal increases from 100 to $200 \mathrm{mg}$, recoveries increase on average for $\mathrm{C}_{2}-\mathrm{C}_{4}$ and $\mathrm{C}_{5}-\mathrm{C}_{9}$ by 20 and $19 \%$, respectively. However, when charcoal increases from 200 to 300 $\mathrm{mg}$, recoveries increase only for $\mathrm{C}_{2}(19 \%), \mathrm{C}_{3}(4 \%)$, and $\mathrm{C}_{4}(8 \%)$ and remain similar for $\mathrm{C}_{5}-\mathrm{C}_{9}$. When charcoal increases from 300 to $500 \mathrm{mg}$, there is no significant increase in recoveries for $\mathrm{C}_{2}-$ $\mathrm{C}_{4}$ (Table 1) whereas contamination levels were higher. Therefore, there is a positive mass charcoal effect on the recoveries for $\mathrm{C}_{2}-$ $\mathrm{C}_{4}$ and $\mathrm{C}_{5}-\mathrm{C}_{9}$ in the ranges $100-300$ and $100-200 \mathrm{mg}$, respectively. The amount of charcoal influences the efficiency of extraction and the level of contamination. Consequently, a mass of $300 \mathrm{mg}$ of activated charcoal with a $100-\mathrm{mL}$ solution acidified at $\mathrm{pH} 1$ was selected as the most valuable conditions since it represents the best compromise between recoveries, blank levels and reproducibility (Table 1 ).

Decarboxylation and Isomerization Processes. The relative low recoveries of $\mathrm{C}_{3}$ (Table 1) may be explained by the presence of $\mathrm{HCl}$ since $\mathrm{C}_{3}$ is very unstable and can be easily decarboxylated. ${ }^{33,34}$ Our laboratory experiments showed that, in the presence of $\mathrm{HCl}$ for few hours, $\mathrm{C}_{3}$ concentration systematically decreases by $30 \%$ compared to nonacidified solutions. Clearly, these results show that, when acid is added, $30 \%$ of the initial amount of $\mathrm{C}_{3}$ is lost by decarboxylation.

For $300 \mathrm{mg}$ of charcoal and $\mathrm{pH} 1$, recoveries of $\mathrm{M}$ and $\mathrm{F}$ are 44 and $115 \%$, respectively (Table 1 ), although no contamination was found for $\mathrm{F}$ in the procedural blanks. $\mathrm{M}$ and $\mathrm{F}$ are two isomers of unsaturated $\mathrm{C}_{4}$ dicarboxylic acid that differ from each other in their cis and trans configurations, respectively. $\mathrm{F}$ can be produced from $\mathrm{M}$ by catalytic isomerization with mineral acids $(\mathrm{HCl}),{ }^{35}$ but such an isomerization does not occur during $\mathrm{BF}_{3} / 1$-butanol derivatization. Consequently, the excess of $\mathrm{F}$ could come from a partial isomerization of $\mathrm{M}$ due to the acidification of the samples before solid-phase extraction. This hypothesis was confirmed by performing experiments with acidified and nonacidified solutions. When a solution containing only $\mathrm{M}\left(50 \mu \mathrm{g} \mathrm{L}^{-1}\right)$ is acidified to $\mathrm{pH}$ 1 for few hours, its concentration decreases by $18 \mu \mathrm{g} \mathrm{L} \mathrm{L}^{-1}(37 \%)$ whereas $\mathrm{F}$ is produced in the same range. Moreover, when a solution containing only $\mathrm{F}$ is passed through $300 \mathrm{mg}$ of charcoal, its recovery of extraction is about $75-80 \%$.

Sorption Capacity of Dicarboxylic Acids onto Charcoal. To assess the sorption capacity of DCAs onto activated charcoal, we performed adsorption and desorption isotherms. A $100-\mathrm{mL}$ aliquot of Milli-Q water (without $\mathrm{NaCl}$ ) was acidified to $\mathrm{pH} 1$, amended in DCAs $\left(10,50,100,200\right.$, and $500 \mu \mathrm{g} \mathrm{\textrm {L } ^ { - 1 }}$ final concentration), and passed through $300 \mathrm{mg}$ of activated charcoal $\left(T=22 \pm 2{ }^{\circ} \mathrm{C}\right)$. Milli-Q water after passing through the charcoal (after neutralization by addition of a strong base) and the regular eluent solution were both analyzed for DCAs. Adsorption isotherm, which represents the relationship between the concentration of

(33) Kühlein, K.; Jensen, H. Liebigs Ann. Chem. 1974, 369-402.

(34) Staikova, M.; Oh, M.; Donaldson, D. J. J. Phys. Chem. A 2005, 109, 597602.

(35) Ihde, A. J. Chem. Educ. 1959, 36, 330 the compound in the liquid solution and the concentration of the compound adsorbed onto charcoal, was linear in the range 10$500 \mu \mathrm{g} \mathrm{L}^{-1}$ for all the compounds ( $R^{2}$ ranging from 0.95 to 0.99 , $n=5$ ), except for glyoxal (none adsorption) and $\omega \mathrm{C}_{2}$ (slight adsorption in the range $100-500 \mu \mathrm{g} \mathrm{L}^{-1}$ ) (data not shown). Desorption isotherm, which represents the relationship between the concentration of the compound in the liquid solution and the concentration of the compound desorbed from charcoal, was linear in the range $10-500 \mu \mathrm{g} \mathrm{L}^{-1}$ for all the compounds ( $R^{2}$ ranging from 0.86 to $0.99, n=5$ ), except for glyoxal (none desorption)

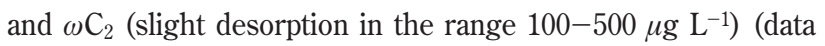
not shown).

To better explain the recoveries of extraction observed, we calculated the percentages of DCAs adsorbed, desorbed, and extracted when using $300 \mathrm{mg}$ of activated charcoal. Results are reported in Table 2 along with the logarithmic octanol/water partition coefficients $\left(\log K_{\text {ow }}\right.$ ) calculated using Environmental Protection Agency (EPA)'s Estimation Program Interface (EPI) suite. $\log K_{\text {ow }}$ represents an index of the water solubility; i.e., compounds with low $\log K_{\text {ow }}$ values $(<1)$ may be considered relatively hydrophilic whereas compounds with high $\log K_{\text {ow }}(>4)$ are generally considered as very hydrophobic. Percentages were corrected for the blank values as well as for the decarboxylation (for $\mathrm{C}_{3}$ ) and isomerization (for $\mathrm{M}$ and $\mathrm{F}$ ) processes (Table 2). Whatever the initial concentration of DCAs, glyoxal is not adsorbed onto charcoal and thus is not extracted from the initial solution (Table 2). Whatever the initial concentration of DCAs, adsorption capacity is close to $100 \%$ for $\mathrm{C}_{4}-\mathrm{C}_{9}, \mathrm{M}, \mathrm{F}$, and $\mathrm{Ph}$ and are around $80-90 \%$ for $\mathrm{C}_{2}$ and $\mathrm{C}_{3}$. Glyoxylic acid is adsorbed onto charcoal from $100 \mu \mathrm{g} \mathrm{\textrm {L } ^ { - 1 }}$ with a lower efficiency $(\sim 25-60 \%)$ whereas $\omega \mathrm{C}_{4}$ is adsorbed from $10 \mu \mathrm{g} \mathrm{L} \mathrm{L}^{-1}$ with a higher efficiency $(\sim 60-80 \%)$ (Table 2). When the initial concentration reaches 500 $\mu \mathrm{g} \mathrm{L} \mathrm{L}^{-1}$, desorption capacity of DCAs decreases, particularly for $\mathrm{C}_{4}-\mathrm{C}_{9}, \mathrm{M}, \mathrm{F}$, and $\mathrm{Ph}$, resulting in a substantial decrease in the percentage of extraction (Table 2). The desorption capacity of $\omega \mathrm{C}_{4}$ $(\sim 20-30 \%)$ and $\mathrm{Ph}(\sim 30-50 \%)$ remains very low for any concentration. Consequently, these percentages show clearly that the adsorption and desorption capacity of DCAs onto $300 \mathrm{mg}$ of activated charcoal is constant up to an initial concentration of 200 $\mu \mathrm{g} \mathrm{\textrm {L } ^ { - 1 }}$ (a slight decrease in desorption capacity was observed for $500 \mu \mathrm{g} \mathrm{L}^{-1}$ ) (Table 2).

In the range of initial concentrations $10-200 \mu \mathrm{g} \mathrm{L} \mathrm{L}^{-1}$, except for $\omega \mathrm{C}_{4}$ and $\mathrm{Ph}$, we observe that, for $\log K_{\mathrm{ow}}$ values ranging from -1.66 (glyoxal) to 0 ( $\mathrm{M}$ and $\mathrm{F}$ ), the percentages of adsorption and desorption tend to increase, which leads to an increase in the percentage of extraction (Table 2). For $\log K_{\text {ow }}$ values ranging from 0 to $2.67\left(\mathrm{C}_{9}\right)$, the percentage of adsorption remains constant close to $100 \%$ whereas the percentage of desorption tends to decrease, which leads to a decrease in the percentage of extraction (Table 2). Clearly, in the range of initial concentrations 10-200 $\mu \mathrm{g} \mathrm{L} \mathrm{L}^{-1}$, the solid-phase extraction of DCAs is driven by both adsorption and desorption in the range of $\log K_{\mathrm{ow}}-1.66$ to 0 and only by desorption in the range of $\log K_{\mathrm{ow}} 0-2.67$. The best agreement between efficient adsorption and desorption is found for compounds with $\log K_{\mathrm{ow}}$ around 0 (M, F and $\mathrm{C}_{4}$ ) (Table 2). Note that (i) the desorption capacity starts decreasing at $500 \mu \mathrm{g}$ $\mathrm{L}^{-1}$ and that (ii) $\omega \mathrm{C}_{4}$ and $\mathrm{Ph}$ do not follow the same trends since 
Table 2. Percentages of DCAs Adsorbed onto and Desorbed from 300 mg of Activated Charcoal and Extracted from the Initial 100-mL Liquid Solution for Different Initial Concentrations $\left(10,50,100,200\right.$, and $500 \mu \mathrm{g} \mathbf{L}^{-1}$ ) ${ }^{a}$ along with the Logarithmic Octanol/Water Partition Coefficients $\left(\log K_{\text {ow }}\right)^{b}$

\begin{tabular}{|c|c|c|c|c|c|c|c|c|c|c|c|c|c|c|c|c|}
\hline \multirow[b]{3}{*}{ compds } & \multirow[b]{3}{*}{$\log K_{\mathrm{ow}}$} & \multicolumn{15}{|c|}{ initial concentrations $\left(\mu \mathrm{g} \mathrm{L}^{-1}\right)$} \\
\hline & & \multicolumn{5}{|c|}{$\begin{array}{c}\% \text { adsorbed onto } \\
\text { charcoal }\end{array}$} & \multicolumn{5}{|c|}{$\begin{array}{c}\% \text { desorbed from } \\
\text { charcoal }\end{array}$} & \multicolumn{5}{|c|}{$\begin{array}{l}\text { \% extracted from } \\
\text { initial solution }\end{array}$} \\
\hline & & $\overline{10}$ & 50 & 100 & 200 & 500 & 10 & 50 & 100 & 200 & 500 & $\overline{10}$ & 50 & 100 & 200 & $\overline{500}$ \\
\hline $\mathrm{C}_{2}$ & -0.77 & 83 & 64 & 93 & 95 & 85 & 73 & 100 & 74 & 61 & 58 & 60 & 64 & 69 & 58 & 49 \\
\hline $\mathrm{C}_{3}$ & -0.28 & 87 & 92 & 91 & 91 & 87 & 75 & 54 & 65 & 64 & 63 & 66 & 50 & 60 & 59 & 55 \\
\hline $\mathrm{C}_{4}$ & 0.21 & 92 & 95 & 95 & 99 & 96 & 102 & 96 & 96 & 91 & 81 & 94 & 91 & 91 & 90 & 77 \\
\hline $\mathrm{C}_{5}$ & 0.7 & 98 & 99 & 96 & 100 & 99 & 89 & 88 & 89 & 86 & 68 & 87 & 87 & 86 & 86 & 68 \\
\hline $\mathrm{C}_{6}$ & 1.2 & 98 & 98 & 96 & 100 & 99 & 88 & 86 & 85 & 82 & 62 & 86 & 84 & 82 & 82 & 61 \\
\hline $\mathrm{C}_{7}$ & 1.69 & 97 & 100 & 96 & 100 & 99 & 79 & 78 & 76 & 73 & 53 & 77 & 78 & 74 & 73 & 53 \\
\hline $\mathrm{C}_{8}$ & 2.18 & 98 & 100 & 97 & 100 & 100 & 88 & 66 & 61 & 52 & 64 & 86 & 66 & 59 & 51 & 64 \\
\hline $\mathrm{C}_{9}$ & 2.67 & 97 & 99 & 97 & 100 & 99 & 71 & 72 & 69 & 64 & 44 & 70 & 71 & 67 & 64 & 44 \\
\hline $\mathrm{M}$ & 0 & 96 & 100 & 97 & 100 & 99 & 103 & 71 & 93 & 103 & 75 & 98 & 71 & 89 & 103 & 75 \\
\hline $\mathrm{F}$ & 0 & 99 & 100 & 96 & 100 & 100 & 77 & 88 & 80 & 70 & 62 & 77 & 87 & 77 & 70 & 62 \\
\hline $\mathrm{Ph}$ & 1.22 & 98 & 99 & 94 & 100 & 99 & 41 & 51 & 43 & 40 & 29 & 40 & 50 & 40 & 40 & 29 \\
\hline$\omega \mathrm{C}_{2}$ & -1.07 & 0 & 0 & 40 & 24 & 56 & 0 & 0 & 4 & 5 & 1 & 1 & 3 & 1 & 1 & 1 \\
\hline$\omega \mathrm{C}_{4}$ & -0.4 & 59 & 83 & 80 & 83 & 69 & 31 & 22 & 21 & 29 & 18 & 18 & 18 & 17 & 24 & 13 \\
\hline glyoxal & -1.66 & 0 & 0 & 0 & 0 & 0 & 0 & 0 & 0 & 0 & 0 & 0 & 1 & 0 & 0 & 0 \\
\hline
\end{tabular}

a $100 \mathrm{~mL}$ Milli-Q water solutions were acidified to $\mathrm{pH} 1$, amended with $10,50,100,200$, and $500 \mu \mathrm{g} \mathrm{L}^{-1}$ of DCAs (initial solutions) and passed through $300 \mathrm{mg}$ of charcoal. The acidified Milli-Q water solutions passing directly through charcoal were collected and neutralized (intermediate solutions). The regular solutions of eluents were then passed through charcoal to desorbed DCAs (final solutions). From the concentrations of DCAs observed in the initial, intermediate, and final solutions, we assessed the percentage of DCA adsorbed onto charcoal $\left(=\left(\left([D C A]_{\text {initial solution }}\right.\right.\right.$ $\left.\left.-[D C A]_{\text {intermediate solution }} /[\mathrm{DCA}]_{\text {initial solution }} \times 100\right)\right)$, the percentage of DCA desorbed from charcoal $\left(=\left([\mathrm{DCA}]_{\text {final }}\right.\right.$ solution $/\left([\mathrm{DCA}]_{\text {initial }}\right.$ solution $\left.\left.\left.[D C A]_{\text {intermediate solution }}\right) \times 100\right)\right)$, and the percentage of DCA extracted from the initial solution $\left(=\left([D C A]_{\text {final solution }} /[D C A]_{\text {initial solution }} \times 100\right)\right)$. All the percentages were corrected for the blank values as well as for the decarboxylation (for $\mathrm{C}_{3}$ ) and isomerization (for $\mathrm{M}$ and $\mathrm{F}$ ) processes. ${ }^{b}$ Log $K_{\mathrm{ow}}$ were estimated using EPA's EPI suite.

their adsorption $\left(\omega \mathrm{C}_{4}\right)$ and desorption $\left(\omega \mathrm{C}_{4}\right.$ and $\left.\mathrm{Ph}\right)$ capacities are lower in regard to their $\log K_{\text {ow }}$ (Table 2).

Concentrations of Dicarboxylic Acids in Seawater Samples. The activated charcoal method was applied to seawater samples. To minimize the blank values, $500-\mathrm{mL}$ samples were acidified to $\mathrm{pH} 1$ and passed trough $300 \mathrm{mg}$ of charcoal. A typical gas chromatogram of the derivatives of DCAs isolated from the seawater sample collected in the Bay of Marseille is presented in Figure 1 . The identification of DCAs was confirmed by GC/MS.

To ensure that the method is consistent with DCA levels in seawater, spike experiments were conducted on surface samples collected in the Bay of Marseille. Table 3 shows the statistical data of the linear regression between the spiked concentration of DCA (from 0.5 to $9.5 \mu \mathrm{g} \mathrm{L}^{-1}$ final concentration) and the measured peak areas corrected for the blank values (in $\mu \mathrm{V}$ s). Different ranges of spiked concentrations were used depending on the initial concentration of the compound in seawater. The method responds linearly to the increasing concentrations of DCAs in seawater for all the compounds including ketocarboxylic acids $\left(R^{2}=0.88, n\right.$ $=5$ and $R^{2}=0.97, n=4$ for $\omega \mathrm{C}_{2}$ and $\omega \mathrm{C}_{4}$, respectively, with slopes significantly different from zero), except for glyoxal, which is not adsorbed onto charcoal $\left(R^{2}=0.30, n=5\right.$ and slope not significantly different from zero) (Table 3 ).

Averaged recoveries of DCAs spiked into seawater samples (Table 3) are not significantly different from those measured in the sodium chloride solutions for $300 \mathrm{mg}$ of charcoal (Table 1), except for $\mathrm{C}_{2}(31 \pm 5$ and $61 \pm 8 \%)$ and $\mathrm{C}_{3}(13 \pm 1$ and $49 \pm 10 \%)$. A hypothesis to explain these lower recoveries found in seawater was a competition with other dissolved organic compounds such as humic substances for the adsorption onto activated charcoal. However, spike experiments conducted on Milli-Q water, Milli-Q water amended in humic acid ( $2 \mathrm{mg} \mathrm{L}^{-1}$ final concentration), and natural river waters (Rhône River, $2.4 \mathrm{mg}$ of $\mathrm{C} \mathrm{L}^{-1}$ ) showed that DCA recoveries are not significantly different $(\mathrm{CV} \pm 8 \%$ for each DCA, data not shown). Consequently, the decrease in $\mathrm{C}_{3}$ could be essentially due to a higher decarboxylation rate according to the higher amount of acid added in the seawater samples. Indeed, we observed experimentally that the rate of decarboxylation was proportional to the amount of acid added in the sample. For $\mathrm{C}_{2}$, the formation of calcium oxalate could occur, leading to a less efficient derivatization. According to the statistical data of the spike experiments in seawater, the activated charcoal method allows a reliable quantification of DCAs in different seawater samples, including ketocarboxylic acids $\left(\omega \mathrm{C}_{2}\right.$ and $\left.\omega \mathrm{C}_{4}\right)$, except glyoxal.

Table 4 presents the averaged concentrations of DCAs (in $\mu \mathrm{g}$ $\mathrm{L}^{-1}$ ) in the northwestern Mediterranean Sea (Bay of Marseille and Dyfamed station), based on duplicate analyses. Concentrations were corrected for procedural blanks. No serious contamination was detected from the procedural blanks, except for $\mathrm{C}_{2}, \mathrm{C}_{3}, \mathrm{C}_{4}$, and $\omega \mathrm{C}_{2}$ for which the blank values represented $14 \pm 6,11 \pm 6$, $14 \pm 8$, and $17 \pm 10 \%$ of the values measured in the different seawater samples, respectively. In all the samples, $\omega \mathrm{C}_{2}$ was found as a dominant species ( $\sim 60-70 \%$ of total DCAs) followed by $\mathrm{C}_{2}$ ( $\sim 20-30 \%$ of total DCAs) and then $\mathrm{C}_{3}$. Total concentrations of DCAs measured in the surface samples are similar: $50 \pm 9$ and $58 \pm 8 \mu \mathrm{g} \mathrm{L}^{-1}$ in the Bay of Marseille and Dyfamed station, respectively. At the Dyfamed station, total concentration of DCAs decreases substantially from 5 to $100 \mathrm{~m}(58 \pm 8$ and $21 \pm 8 \mu \mathrm{g}$ $\mathrm{L}^{-1}$, respectively). However, the decrease is lower from 100 to $1500 \mathrm{~m}\left(21 \pm 8\right.$ and $16 \pm 1 \mu \mathrm{g} \mathrm{L} \mathrm{L}^{-1}$, respectively). Total concentrations of DCAs at $0,5,100$, and $1500 \mathrm{~m}$ represent 1.9, $2.4,0.9$, and $1.1 \%$ of DOC concentration, respectively (Table 4 ).

The distribution of DCAs into the water column (highest values in surface and diminution with depth) suggests that they are 


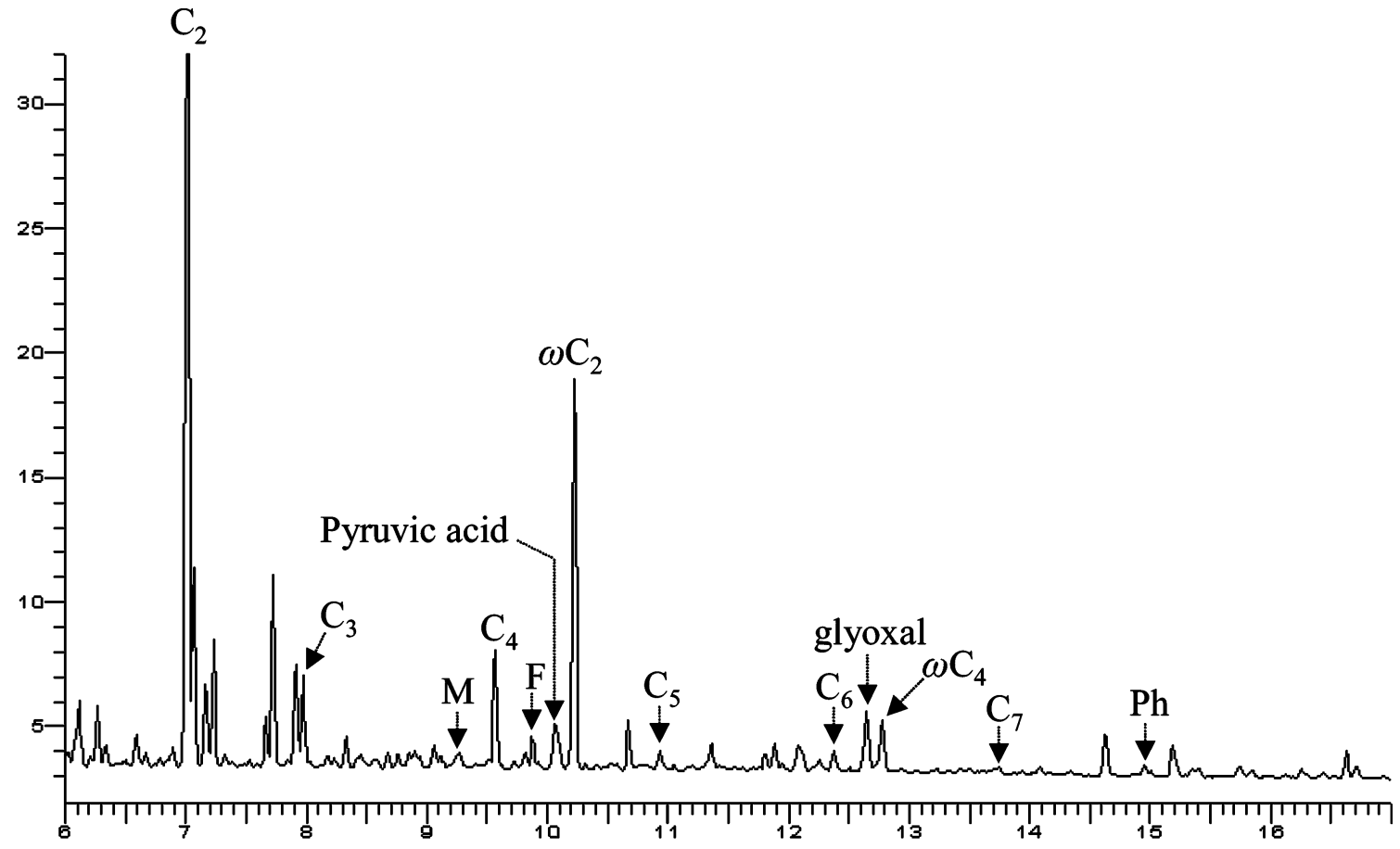

Figure 1. Typical capillary gas chromatogram of the derivatives of dicarboxylic acids $\left(\mathrm{C}_{2}-\mathrm{C}_{9}\right)$, ketocarboxylic acids $\left(\omega \mathrm{C}_{2}, \omega \mathrm{C}_{4}\right.$, pyruvic acid), and dicarbonyl (glyoxal) isolated from the seawater sample collected in the Bay of Marseille (northwestern Mediterranean Sea) in September 2005. The identification of DCAs was confirmed by GC/MS. Pyruvic acid was tentatively identified. Mass spectra of the organic acid butyl esters (not presented here) are equal to those published in the literature. ${ }^{30}$ See Table 1 for the abbreviation of compounds.

Table 3. Statistical Data of the Linear Regression between the Spiked Concentration of DCA in Seawater (0.1-9.5 $\mu \mathrm{g} \mathrm{L}^{-1}$ Final Concentration) and the Measured Peak Area (in $\mu \mathrm{V}$ s) ${ }^{a}$

\begin{tabular}{|c|c|c|c|c|c|c|}
\hline compds & $\begin{array}{l}\text { spiked concn } \\
\left(\mu \mathrm{g} \mathrm{L}^{-1}\right)\end{array}$ & $n$ & $R^{2}$ & $\begin{array}{c}\text { slope } \\
\left(\mu \mathrm{V} \mathrm{s} / \mu \mathrm{g} \mathrm{L}^{-1}\right)\end{array}$ & $\begin{array}{c}y \text {-intercept } \\
(\mu \mathrm{V} \mathrm{s})\end{array}$ & $\begin{array}{c}\text { recovery } \\
(\%)\end{array}$ \\
\hline $\mathrm{C}_{2}$ & $0,2,4.5,7,9.5$ & 5 & 0.94 & $7763 \pm 1171^{\star \star}$ & $85055 \pm 6701^{\star *}$ & $31 \pm 5$ \\
\hline $\mathrm{C}_{3}$ & $0,2,4.5,7,9.5$ & 5 & 0.99 & $2735 \pm 114^{\star \star *}$ & $5415 \pm 655^{\star \star}$ & $13 \pm 1$ \\
\hline $\mathrm{C}_{4}$ & $0,0.5,1,1.5$ & 4 & 0.98 & $15387 \pm 1426^{\star *}$ & $10126 \pm 1334^{* *}$ & $77 \pm 8$ \\
\hline $\mathrm{C}_{5}$ & $0,0.1,0.2,0.5$ & 4 & 0.99 & $14228 \pm 1238^{\star *}$ & $2516 \pm 339^{*}$ & $83 \pm 12$ \\
\hline $\mathrm{C}_{6}$ & $0,0.5,1,1.5$ & 4 & 0.99 & $13075 \pm 258^{\star \star *}$ & $3226 \pm 241^{* *}$ & $79 \pm 2$ \\
\hline $\mathrm{C}_{7}$ & $0,0.1,0.2,0.5$ & 4 & 0.99 & $12395 \pm 157^{* * *}$ & $1059 \pm 43^{* *}$ & $66 \pm 2$ \\
\hline $\mathrm{C}_{8}$ & $0,0.5,1,1.5$ & 4 & 0.99 & $11786 \pm 391^{* * *}$ & $676 \pm 366^{\mathrm{ns}}$ & $64 \pm 2$ \\
\hline $\mathrm{C}_{9}$ & $0,0.5,1,1.5$ & 4 & 0.99 & $12431 \pm 228^{\star \star *}$ & $899 \pm 213^{\mathrm{ns}}$ & $71 \pm 1$ \\
\hline $\mathrm{M}$ & $0,0.1,0.2,0.5$ & 4 & 0.99 & $6862 \pm 432^{\star *}$ & $2609 \pm 118^{* *}$ & $36 \pm 3$ \\
\hline $\mathrm{F}$ & $0,0.1,0.2,0.5$ & 4 & 0.99 & $22976 \pm 1518^{* *}$ & $1670 \pm 415^{\mathrm{ns}}$ & $111 \pm 14$ \\
\hline $\mathrm{Ph}$ & $0,0.1,0.2,0.5$ & 4 & 0.99 & $7829 \pm 351^{\star *}$ & $1761 \pm 96^{\star \star}$ & $41 \pm 7$ \\
\hline$\omega \mathrm{C}_{2}$ & $0,2,4.5,7,9.5$ & 5 & 0.88 & $855 \pm 181^{*}$ & $24006 \pm 1035^{* * *}$ & $2 \pm 1$ \\
\hline$\omega \mathrm{C}_{4}$ & $0,0.5,1,1.5$ & 4 & 0.97 & $4969 \pm 666^{\star}$ & $4036 \pm 623^{\star}$ & $15 \pm 2$ \\
\hline glyoxal & $0,2,4.5,7,9.5$ & 5 & 0.30 & $107 \pm 95^{n s}$ & $3262 \pm 544^{* *}$ & nd \\
\hline
\end{tabular}

${ }^{a}$ Measured peak areas used for the linear regressions were corrected for the blank values. Averaged recoveries of DCAs in seawater samples were determined from the different spiked concentrations and are given with a standard deviation based on $n-1$ analyses. Spike experiments were conducted on surface seawater samples collected in the Bay of Marseille (northwestern Mediterranean Sea) in September 2005. Samples $(500 \mathrm{~mL})$ were acidified to $\mathrm{pH} 1$, amended with DCAs, passed trough $300 \mathrm{mg}$ of charcoal, eluted, and derivatized. Slopes and $y$-intercepts are very highly significantly $\left({ }^{* *}, p<0.001\right)$, highly significantly $\left({ }^{*}, p<0.01\right)$, significantly $\left({ }^{*}, p<0.05\right)$, or not significantly (ns, $\left.p<0.1\right)$ different from zero ( $t$-test). nd, not determined.

produced mainly into the euphotic zone by phytoplankton activities and probably by the photochemical degradation of DOM, whereas they would be consumed mainly by bacterial activities in the whole water column. In seawater, some DCAs (particularly oxalic acid) can be complexed with metals such as iron $\left(\mathrm{Fe}^{3+}\right)$ to form strong iron-binding ligands. ${ }^{36}$ But when the seawater sample is acidified at $\mathrm{pH} 1$ before solid-phase extraction, a major part of these ligands are reduced $\left(\mathrm{Fe}^{2+}\right)$ and release oxalic acid. Therefore, using the

(36) Zuo, Y.; Hoigné, J. Atmos. Environ. 1994, 28, 1231-1239. activated charcoal method, we may analyze free as well as complex forms of DCAs, particularly for oxalic acid.

At the Dyfamed station, glyoxylic and oxalic acids concentrations represent 39, 12, and 8 and $14,6.5$, and $5 \mu \mathrm{g} \mathrm{L} \mathrm{L}^{-1}$ at 5, 100, and $1500 \mathrm{~m}$, respectively (Table 4). These concentrations are in the same range as those previously reported in the Pacific Ocean with 22.2, 5.2, and 7.4 and 9, 3.6 and $20 \mu \mathrm{g} \mathrm{L} \mathrm{L}^{-1}$ for glyoxylic and oxalic acids at 75,100 , and $1800 \mathrm{~m}$, respectively. ${ }^{20}$ Therefore, according to the concentrations of DCAs measured in this study, 
Table 4. Concentrations of DCAs (in $\mu \mathrm{g} \mathrm{L}^{-1}$ ) in Natural Seawater Samples (Bay of Marseille and Dyfamed Station, Northwestern Mediterranean Sea)a

\begin{tabular}{lc} 
& Bay of Marseille \\
\cline { 2 - 2 } compds & $0 \mathrm{~m}$ \\
$\mathrm{C}_{2}$ & $12.55 \pm 2.25$ \\
$\mathrm{C}_{3}$ & $2.40 \pm 0.59$ \\
$\mathrm{C}_{4}$ & $0.74 \pm 0.11$ \\
$\mathrm{C}_{5}$ & $0.15 \pm 0.04$ \\
$\mathrm{C}_{6}$ & $0.21 \pm 0.05$ \\
$\mathrm{C}_{7}$ & $0.08 \pm 0.00$ \\
$\mathrm{C}_{8}$ & nd \\
$\mathrm{C}_{9}$ & nd \\
$\mathrm{M}$ & $0.36 \pm 0.02$ \\
$\mathrm{~F}$ & $\mathrm{nd}$ \\
$\mathrm{Ph}$ & $0.24 \pm 0.02$ \\
$\omega \mathrm{C}_{2}$ & $32.31 \pm 5.99$ \\
$\omega \mathrm{C}_{4}$ & $0.95 \pm 0.19$ \\
glyoxal & nd \\
pyruvic & nd \\
total & $50.07 \pm 9.05$ \\
$\%$ DOC & $1.9 \pm 0.3$
\end{tabular}

\begin{tabular}{ccc} 
& Dyfamed station & \\
\hline $5 \mathrm{~m}$ & $100 \mathrm{~m}$ & $1500 \mathrm{~m}$ \\
$13.71 \pm 2.03$ & $6.48 \pm 2.45$ & $5.39 \pm 0.37$ \\
$2.25 \pm 0.02$ & $0.71 \pm 0.31$ & $0.60 \pm 0.07$ \\
$0.44 \pm 0.08$ & $0.12 \pm 0.04$ & $0.17 \pm 0.06$ \\
$0.16 \pm 0.03$ & $0.04 \pm 0.02$ & $0.08 \pm 0.05$ \\
$0.34 \pm 0.00$ & $0.17 \pm 0.08$ & $0.29 \pm 0.15$ \\
0.00 & 0.00 & 0.00 \\
0.00 & 0.00 & 0.00 \\
$0.16 \pm 0.02$ & nd & nd \\
$0.79 \pm 0.13$ & $0.43 \pm 0.18$ & $0.34 \pm 0.13$ \\
nd & nd & nd \\
$0.46 \pm 0.10$ & $0.12 \pm 0.03$ & $0.27 \pm 0.12$ \\
$38.96 \pm 5.60$ & $12.41 \pm 4.50$ & $8.45 \pm 1.05$ \\
$1.01 \pm 0.16$ & $0.27 \pm 0.09$ & $0.31 \pm 0.08$ \\
nd & nd & nd \\
nd & nd & nd \\
$58.28 \pm 7.59$ & $20.78 \pm 7.70$ & $15.93 \pm 0.99$ \\
$2.4 \pm 0.3$ & $0.9 \pm 0.3$ & $1.1 \pm 0.05$
\end{tabular}

${ }^{a}$ Averaged concentrations are corrected for the blank values and are given with a standard deviation based on duplicate analysis. For the Bay of Marseille, concentrations were determined by dividing the $y$-intercept of the linear regression (corrected by the blank value) by the slope of the linear regression (values reported in Table 3). For the Dyfamed station, the same slopes were used with the measured peak area (also corrected by the blank value and analyzed with $t$-test). Seawater samples $(500 \mathrm{~mL})$ were collected in September and October 2005 , acidified to pH 1 , passed through $300 \mathrm{mg}$ of charcoal, eluted, and derivatized. nd, not determined, used when a peak is detected but the compound cannot be quantified because of an unknown slope (pyruvic acid) or a slope (glyoxal) or a $y$-intercept/measured peak area $\left(\mathrm{C}_{8}, \mathrm{C}_{9}, \mathrm{~F}\right)$ not significantly different from zero. A concentration of $0.00 \mu \mathrm{g} \mathrm{L} \mathrm{L}^{-1}$ means that the peak is not detected.

glyoxylic acid $\left(8-40 \mu \mathrm{g} \mathrm{L}^{-1}\right)$ could be, with glycolic acid (24-89 $\mu \mathrm{g} \mathrm{L}-1),{ }^{37}$ one of the major low molecular weight dissolved organic compounds in seawater.

\section{CONCLUSION}

We have developed a new analytical technique to measure low molecular weight DCAs $\left(\mathrm{C}_{2}-\mathrm{C}_{9}\right)$ in natural seawater samples. This technique consists of adsorption of DCAs from acidified seawater onto activated, pretreated charcoal following by desorption using different eluents. DCAs are then derivatized with $\mathrm{BF}_{3} / 1$-butanol to dibutyl esters and determined with GC/FID-MS. The method was first tested in sodium chloride solutions using different $\mathrm{pH}$ and different amounts of charcoal and then applied to real seawater samples. The recoveries of DCAs from the spiked sodium chloride solutions acidified at $\mathrm{pH} 1$ for $300 \mathrm{mg}$ of charcoal were found to be $49-96 \%$ with standard deviation of $3-10 \%$ for different DCAs. We observed that glyoxylic acid was the dominant species in the seawater samples with a concentration range of $8-40 \mu \mathrm{g} \mathrm{L} \mathrm{L}^{-1}$. Those concentrations suggest that glyoxylic acid could be one of the major low molecular weight dissolved organic compounds in seawater. Total DCAs and related water-soluble compounds account for $0.9-2.4 \%$ DOC in the seawater samples.

\section{ACKNOWLEDGMENT}

We thank M. Goutx and C. Guigue for the use of the CG/FID system. We thank also J.F. Rontani for his helpful comments as well as the anonymous reviewers for improving the quality of the manuscript. We thank J.C. Marty and S. Gouy for providing seawater samples. This study was supported by the CNRS-PROOF UVECO project, the region Provence Alpes Côte d'Azur, the College Doctoral Franco-Japonais, Airmaraix, and also by Japanese Ministry of Education, Culture, Sports, Science, and Technology through grant-in-aid 01470041.

(37) Leboulanger, C.; Descolas-Gros, C.; Jupin, H. J. Plankton Res. 1994, 16, $897-903$. 